\title{
Non-Steroidal Anti-Inflammatory Drugs and Vitamin C in the Rotenone Induced Nigrostriatal Damage in Mice
}

\author{
Nagi Ali Ibrahim ${ }^{1, ~ *, ~ O m a r ~ M o h a m e d ~ A b d e l-S a l a m ², ~ Y a s s e r ~ A s h r y ~ K h a d r a w y, ~}$ \\ Amal Mohamed Hashem ${ }^{1}$, Eman Mohamed Sameer ${ }^{1}$ \\ ${ }^{1}$ Department of Zoology, Faculty of Science, Zagazig University, Zagazig, Egypt \\ ${ }^{2}$ Department of Toxicology and Narcotics, National Research Center, Dokki, Giza, Egypt \\ ${ }^{3}$ Department of Medical Physiology, National Research Center, Dokki, Giza, Egypt
}

Email address:

Nagiibrahim_1050@yahoo.com (N. A. Ibrahim)

*Corresponding author

\section{To cite this article:}

Nagi Ali Ibrahim, Omar Mohamed Abdel-Salam, Yasser Ashry Khadrawy, Amal Mohamed Hashem, Eman Mohamed Sameer. NonSteroidal Anti-Inflammatory Drugs and Vitamin C in the Rotenone Induced Nigrostriatal Damage in Mice. European Journal of Clinical and Biomedical Sciences. Vol. 3, No. 4, 2017, pp. 67-79. doi: 10.11648/j.ejcbs.20170304.11

Received: April 15, 2017; Accepted: June 20, 2017; Published: July 4, 2017

\begin{abstract}
The nigrostriatal pathway is a dopaminergic pathway that connects the substantia nigra with the dorsal striatum. Loss of dopamine neurons in the substantia nigra is one of the main pathological features of Parkinson's disease, leading to a marked reduction in dopamine function in this pathway. This study aimed at evaluating the protective role of two antiinflammatory drugs, indomethacin and nimesulide separately or in combination with vitamin $\mathrm{C}$ against biochemical disturbances, brain damage and motor impairment in rotenone-induced mice model of Parkinson's disease. Animals were divided into 7 groups. $1^{\text {st }}$ received the vehicle (DEMSO); $2^{\text {nd }}$ received rotenone $(1.5 \mathrm{mg} / \mathrm{kg}) ; 3^{\text {rd }}$ received rotenone then were left for two weeks recovery; $4^{\text {th }}$ rotenone + indomethacin $(10 \mathrm{mg} / \mathrm{kg}) ; 5^{\text {th }}$ received rotenone + indomethacin in combination with vitamin $C(25 \mathrm{mg} / \mathrm{kg}) .6^{\text {th }}$ received rotenone + nimesulide $(10 \mathrm{mg} / \mathrm{kg})$; group 7 received rotenone + nimesulide in combination with vitamin $\mathrm{C}$. All treatments were given subcutaneously three times per week for one month. Rotenone treatment caused significant Increases in brain malondialdehyde (MDA), nitric oxide (NO), but induced significant decreases in brain reduced glutathione (GSH) level, acetylcholinesterase (AChE) activity, dopamine (DA), norepinephrine (NE) and serotonin (5-HT) levels. These changes lasted for two weeks after the termination of rotenone treatment. Histologically, Rotenone caused degeneration of neurons in striatum, cellular infiltration, atrophy, pyknosis, necrosis, as well as focal gliosis in cerebral cortex and pyknosis of pyramidal cells in the hippocampus. Furthermore, rotenone treatment caused a significant impairment in the motor function of the mice (stair test). Co-administration of indomethacin or nimesulide separately or in combination with vitamin $\mathrm{C}$ to rotenone treated mice resulted in alleviation of biochemical and motor activity but not the histological disturbances caused by rotenone treatment alone.
\end{abstract}

Keywords: Parkinson's Disease, Substantia Nigra, Striatum, Nigrostriatal, Rotenone, Indomethacin, Nimesulide

\section{Introduction}

Parkinson's disease (PD) is a late-onset, progressive motor syndrome, marked by selective degeneration of the dopaminergic neurons of the substantia nigra $(\mathrm{SN})$ in the midbrain $[1,2]$. After losing about $50 \%$ of the dopaminergic neurons and approximately 75 to $80 \%$ of striatal dopamine (DA), progressive bradykinesia, resting tremor and rigidity start to appear [3, 4]. Degeneration of dopamine-containing cells in the SN and depigmentation of this brain area are considered as the main pathological features of PD [5]. Although the loss of dopaminergic neurons of the SNpc is regarded as the best pathological feature of $\mathrm{PD}$, many other types of neurons are degenerated such as neurons in the serotonergic raphe nuclei, the noradrenergic locus coeruleus, and regions of the cerebral cortex and the peripheral nervous system [6], and a marked loss of both noradrenergic and serotonergic neurons occurs [7], so neurotransmitters like norepinephrine and serotonin are affected by the DA deficiency in PD [8]. The exact cause leading to the selective 
loss of dopamine secreting cells of the $\mathrm{SN}$ is not yet known but an interaction between environmental and genetic factors is suggested to be involved in the etiology of PD [9], and researchers have reported the correlation between the exposure to insecticides and herbicides such as rotenone and paraquat and the increasing risk of PD $[10,11]$. Among the molecular mechanisms involved in the pathogenesis of PD, oxidative stress, mitochondrial dysfunction, and neuroinflammation are the most strongly implicated $[12,13$, 14]. Mitochondria are regarded as the main source of endogenous reactive oxygen species $[15,16]$. These highly reactive oxygen intermediates lead to apoptosis and cell death by interacting with proteins, DNA and RNA [17, 18]. The free radical $\mathrm{NO}^{\circ}$ is a biological molecule that plays a key role in many physiological conditions [19]. Increased production of $\mathrm{NO}^{\circ}$, however, can be associated with oxidative and/or nitrative stress and subsequent neuronal damage. This has been attributed to its reaction with superoxide radical and the production of the highly reactive peroxynitrite radical [20]. The excess free radicals result in lipid peroxidation (LP) and oxidative stress in the SN and finally lead to neurodegeneration [21]. Increased lipid peroxidation, and DNA oxidation have been reported in the brain tissue from PD patients post-mortem [22]. A major antioxidant in the brain, that is glutathione (GSH) is very beneficial for the cells as it plays an important role in maintaining their redox status [23]. Gluathione was reported to be decreased in brains of PD patients [24]. The reduction of the GSH content in the brain is a marker of oxidative damage [25].

There is growing evidence that points to the significant role of neuroinflammation in the pathogenesis of PD [26]. The inflammatory process in the $\mathrm{SN}$ is mainly characterized by the presence of activated microglial cells and the secretion of proinflammatory and neurotoxic factors [27]. Cytokines are involved in the pathogenesis of PD [28] as they induce the production of cyclooxygenase enzymes (COXs) which generate important mediators during the inflammatory reaction [29]. The cyclooxygenase enzyme catalyzes the first two steps of the biosynthesis of prostaglandins (PGs) from the substrate arachidonic acid [29]. It converts arachidonic acid to prostaglandin $\mathrm{H} 2$ (PGH2), the precursor of prostaglandin E2 (PGE2) and other prostanoids [30]. It was later revealed that cyclooxygenase enzyme had two distinct isoforms, identified as cyclooxygenase-1 (COX-1) and cyclooxygenase-2 (COX-2) with distinct cellular functions [31].

Non-steroidal anti-inflammatory drugs (NSAIDs) are compounds which nevertheless share common mechanism of action [32]. They have the ability to inhibit the PGs synthesis [33]. NSAIDs are one of the most commonly prescribed drugs in the world that are known to treat pain and inflammation [34]. Several studies suggest that antiinflammatory drugs generally have a protective effect on PD in humans, possibly by reducing neuroinflammation $[35,36]$. Other researchers, however, failed to demonstrate a benefit from NSAIDs in relation to the development of $\mathrm{PD}[37,38$,
39]. Indomethacin is a non-selective NSAID which is widely used in the treatment of various rheumatic conditions [40]. It was demonstrated that indomethacin protected dopaminergic neurons in the $\mathrm{SN}$, protected against MPTP induced neurotoxicity and decreased microglial activation in the MPTP mouse model of PD but the drug appeared to be toxic at high doses [41]. COX-2 inhibitors (COXIBs) are regarded as the most widely used medications nowadays because these lack the adverse effects of the classic non-selective drugs on the stomach and kidney [42]. Nimesulide is an analgesic, antipyretic and anti-inflammatory drug and it is relatively selective COX-2 inhibitor [43]. These effects of nimesulide are based on its inhibition of PGs synthesis [44]. According to many experimental studies, nimesulide has neuroprotective effect and produces a long lasting neuroprotection $[45,46]$.

The present study investigates two NSAIDs, namely indomethacin and nemisulide on their ability to modulate brain oxidative stress, brain damage and motor impairment induced in the mouse by systemic rotenone injection. Rotenone is a pesticide that has been widely used in rodents to model human PD. It is a complex I inhibitor [47], and was shown to cause nigrostriatal cell death and pathological and behavioral changes that resemble those found in the brain of patients with PD [48].

\section{Materials and Methods}

\subsection{Animals}

Swiss male albino mice, weighing 25-26 g were obtained from the breeding colony maintained at the animal house of National Research Center, Cairo, Egypt. Animal procedures were performed in accordance with the ethics committee of the National Research Centre and followed the recommendations of the National Institutes of Health Guide for Care and Use of Laboratory Animals.

\subsection{Drugs and Chemicals}

Rotenone was obtained from Sigma-Aldrich (St Louis, MO, USA). Indomethacin (Kahira Pharm. and Chem. Ind. Co., Cairo, Egypt), nimesulide (Hikma Pharma, S. A. E., 6th of October city, Egypt) and vitamin C ampoules ( Pharm. and Chem. Ind. Co., Cairo, Egypt) were used. Rotenone was freshly prepared in $100 \%$ dimethyl sulfoxide. Indomethacin, nemisulide and vitamin $\mathrm{C}$ were dissolved in distilled water to obtain the necessary doses. All the used chemicals and reagents in the present study were of analytical grade and obtained from Sigma-Aldrich.

\subsection{Experimental Design}

The mice were randomly divided into seven groups (6 animals each), Group 1 received the vehicle (DEMSO) three times a week; group 2 received a subcutaneous injection of rotenone $(1.5 \mathrm{mg} / \mathrm{kg})$ three times per week for one month; group 3 received rotenone for one month then left for two weeks for recovery; group 4 received subcutaneous injection 
of $\mathrm{r}$ otenone $1.5 \mathrm{mg} / \mathrm{kg}+$ indomethacin $10 \mathrm{mg} / \mathrm{kg}$ three times per week; group 5 received the same of group 4 but in combination with vitamin C $25 \mathrm{mg} / \mathrm{kg}$ subcutaneously; group 6 received subcutaneous injection of rotenone 1.5 $\mathrm{mg} / \mathrm{kg}+$ nimesulide $10 \mathrm{mg} / \mathrm{kg}$ three times per week; group 7 received the same of group 6 but in combination with vitamin C $25 \mathrm{mg} / \mathrm{kg}$ subcutaneously. All animals received the treatments for one month and were then euthanized by decapitation under ether anesthesia; brains were then quickly dissected out on an ice-cold plate into right halves and left halves, weighed, washed with ice-cold phosphatebuffered saline (PBS $\mathrm{pH} 7.4$ ), and stored at $-80^{\circ} \mathrm{C}$ until biochemical analyses. The right halves were used for the determination of neurotransmitters, namely dopamine, norepinephrine and serotonin. The left halves were used for the determination of glutathione (GSH), malondialdehyde (MDA) and nitric oxide (NO). The tissues were homogenized with $0.1 \mathrm{M}$ phosphate buffer saline at $\mathrm{pH} 7.4$, to give a final concentration of $10 \% \mathrm{w} / \mathrm{v}$ for the biochemical assays. Homogenization was performed using a homogenizer (ULTRA-TURAX, IKA T10 basic, Germany) at speed $5000 \mathrm{rpm}$ for 30 seconds. For the determination of monoamine neurotransmitters, frozen samples were homogenized in cold $0.1 \mathrm{~N}$ perchloric acid.

\subsection{Biochemical Analysis}

\subsubsection{Determination of Lipid Peroxidation}

Lipid peroxidation was assayed by measuring the level of malondialdehyde in brain tissues. Malondialdehyde was determined by measuring thiobarbituric acid-reactive species according to the method devised by Ruiz-Larrea et al (1994) [49], in which thiobarbituric acid-reactive substances react with thiobarbituric acid to produce a red-colored complex having peak absorbance at $532 \mathrm{~nm}$. In brief, $2.25 \mathrm{~mL}$ of working reagent (one volume of $0.8 \mathrm{~g}$ thiobarbituric acid dissolved in $100 \mathrm{~mL}$ of $10 \%$ perchloric acid and three volumes of $20 \%$ trichloroacetic acid) were added to $0.25 \mathrm{~mL}$ of sample, incubated for 20 minutes in a boiling water bath, and then left to cool at room temperature before centrifugation at $3,000 \mathrm{rpm}$ for 5 minutes at $0^{\circ} \mathrm{C}$. The pink color was measured using a ultraviolet (UV)-VI8 recording spectrophotometer (Shimadzu Corporation, Rydalmere, Australia) at a $532 \mathrm{~nm}$ wavelength against the blank solution, which was prepared by addition of $0.25 \mathrm{~mL}$ of distilled water to $2.25 \mathrm{~mL}$ of working reagent.

\subsubsection{Determination of Reduced Glutathione}

Reduced glutathione was determined in the supernatants by Ellman's method (1959) [50]. This procedure is based on the reduction of Ellman's reagent by $-\mathrm{SH}$ groups of glutathione to form 2-nitro-s-mercaptobenzoic acid; the nitromercaptobenzoic acid anion has an intense yellow color which can be determined spectrophotometrically using a UVVI8 recording spectrophotometer. The reduced glutathione concentration was calculated by comparison with a standard curve.

\subsubsection{Determination of Nitric Oxide}

Nitric oxide measured as the nitrite was determined using Griess reagent, according to the method devised by Moshage et al (1995) [51], which is based on measurement of endogenous nitrite concentration as an indicator of nitric oxide production. It depends on the addition of Griess reagent which converts nitrite into a deep purple azo compound, the absorbance of which is read at $540 \mathrm{~nm}$.

\subsubsection{Determination of Acetylcholinesterase Activity}

Acetylcholinesterase (AChE) activity was determine according to the modification in Ellman et al method (1961) [52], as described by Gorun et al (1978) [53]. The principle of the method involves mea $\neg$ surement of the thiocholine produced as acetylthiocholine is hydrolyzed. The color was read immediately at $412 \mathrm{~nm}$. The following reagents were pipetted in a cuvette: $0.14 \mathrm{~mL}$ of phosphate buffer $20 \mathrm{mM}$ $(\mathrm{pH} 7.6), 0.05 \mathrm{~mL}$ of $5 \mathrm{mM}$ acetylthiocholine iodide, and $0.01 \mathrm{~mL}$ of tissue homogenate. After 10 minutes of incubation at $38^{\circ} \mathrm{C}$, the reaction was stopped with $1.8 \mathrm{~mL}$ of 5,5'-dithiobis-2-nitrobenzoic acid (DTNB)-phosphate ethanol reagent. The DTNB-phosphate ethanol reagent was prepared by dissolving $12.4 \mathrm{mg}$ of DTNB in $120 \mathrm{~mL}$ of $96 \%$ ethanol, $80 \mathrm{~mL}$ of distilled water, and $50 \mathrm{~mL}$ of 0.1 $\mathrm{mM}$ phosphate buffer ( $\mathrm{pH}$ 7.6). Glutathione $2.5 \mathrm{mM}$ was used as the standard.

\subsubsection{Determination of Monoamine Levels}

Estimation of 5-HT, NE and DA was carried out according to the fluorometric method described by Ciarlone (1978) [54]. The method involves extraction of the monoamines into butanol, return of the amine to an aqueous phase and conversion to a fluorescent derivative by oxidation [55].

\subsection{Motor Activity}

Stair test was applied to assess skilled reaching, mice were placed at the bottom of a stair $(30 \mathrm{~cm}$ in length) placed at an angle of $55^{\circ}$ above the bench, and the latency to climb the stair is recorded for each mouse [56].

\subsection{Histopathological Studies}

The brain tissues (right half) were immediately fixed in $10 \%$ formalin, dehydrated in gradual ethanol (50-100\%), cleared in xylene and embedded in paraffin. Sections $(4 \mu \mathrm{m})$ were prepared and then stained with hematoxylin and eosin (H\&E) dye for photomicroscopic observations. Sections were examined using a light microscope.

\subsection{Statistical Analysis}

The data are expressed as the mean \pm standard error of the mean. The data were analyzed by one-way analysis of variance followed by Tukey's test, using SPSS software (SPSS Inc., Chicago, IL, USA). A P-value of less than 0.05 was considered statistically significant. 


\section{Results}

\subsection{Malondialdehyde}

The administration of rotenone $(1.5 \mathrm{mg} / \mathrm{kg})$ significantly $(\mathrm{P}<0.05)$ increased MDA level by $82.2 \%$ compared to vehicle-treated control group. After 2 weeks recovery period from rotenone treatment, MDA level was not significantly decreased $(\mathrm{P}>0.05)$ compared to rotenone-treated mice. Indomethacin administration at a dose of $10 \mathrm{mg} / \mathrm{kg}$ had no effect on MDA level relative to rotenone-treated mice $(\mathrm{P}>0.05)$, while was still significant $(\mathrm{P}<0.05)$ from vehicletreated control group. On the other hand, treatment with indomethacin $(10 \mathrm{mg} / \mathrm{kg})$ combined with vitamin $\mathrm{C}$ (25 $\mathrm{mg} / \mathrm{kg})$ significantly $(\mathrm{P}<0.05)$ decreased MDA level by $20.5 \%$ relatively to rotenone-treated group. Nimesulide administration at a dose of $10 \mathrm{mg} / \mathrm{kg}$ caused marked $(\mathrm{P}<0.05)$ decrease of MDA level by $26.2 \%$ in relation to rotenonetreated group. After treatment with nimesulide $(10 \mathrm{mg} / \mathrm{kg})$ combined with vitamin C (25 mg/kg) MDA level did not significantly $(\mathrm{P}>0.05)$ change compared to rotenone-treated group, while was still significant $(\mathrm{P}<0.05)$ from vehicle group (Figure 1).

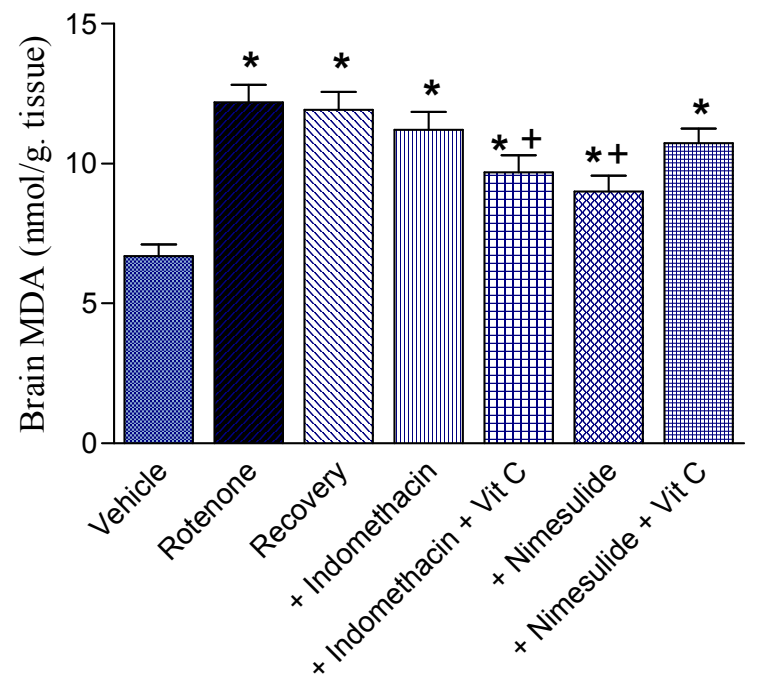

Figure 1. Effect of treatment with indomethacin or nimesulide alone or combined with vitamin $C$ on malondialdehyde (MDA) in mice brain after rotenone treatment. $* P<0.05$ compared with the vehicle group. $+P<0.05$ compared with rotenone control group.

\subsection{Reduced Glutathione}

The administration of rotenone $(1.5 \mathrm{mg} / \mathrm{kg})$ induced a significant $(\mathrm{P}<0.05)$ reduction to $\mathrm{GSH}$ level by $35.2 \%$ compared to vehicle-treated control group. After 2 weeks recovery period from rotenone treatment GSH level was not restored $(\mathrm{P}>0.05)$ compared to rotenone-treated mice. GSH level was markedly $(\mathrm{P}<0.05)$ elevated by $57.5 \%$ in comparison to rotenone-treated mice after Indomethacin administration at a dose of $(10 \mathrm{mg} / \mathrm{kg})$. Treatment with indomethacin $(10 \mathrm{mg} / \mathrm{kg})$ combined with vitamin $\mathrm{C}(25$ $\mathrm{mg} / \mathrm{kg})$ markedly $(\mathrm{P}<0.05)$ increased $\mathrm{GSH}$ level by $30.1 \%$ relatively to rotenone-treated group. Nimesulide administration at a dose of $(10 \mathrm{mg} / \mathrm{kg})$ caused significant $(\mathrm{P}<0.05)$ elevation to GSH level by $55.43 \%$ in relation to rotenone-treated group. On the other hand, after treatment with nimesulide $(10 \mathrm{mg} / \mathrm{kg})$ combined with vitamin $\mathrm{C}(25$ $\mathrm{mg} / \mathrm{kg}) \mathrm{GSH}$ level markedly $(\mathrm{P}<0.05)$ elevated by $65.5 \%$ (Figure2).

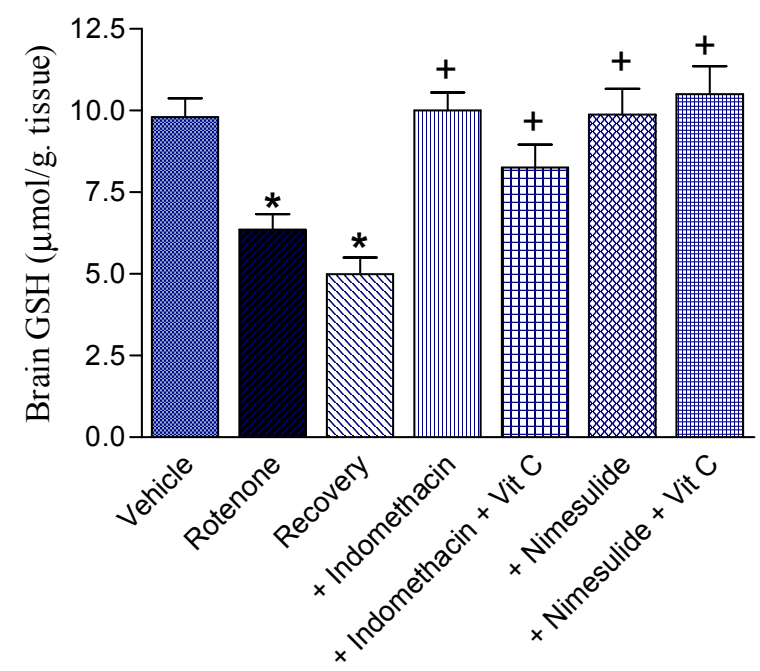

Figure 2. Effect of treatment with indomethacin or nimesulide alone or combined with vitamin $C$ on reduced glutathione (GSH) in mice brain after rotenone treatment. $* P<0.05$ compared with the vehicle group. $+P<0.05$ compared with rotenone control group.

\subsection{Nitric Oxide}

The administration of rotenone $(1.5 \mathrm{mg} / \mathrm{kg})$ significantly $(\mathrm{P}<0.05)$ increased nitric oxide level by $60.91 \%$ compared to vehicle-treated control group. After 2 weeks recovery period from rotenone treatment nitric oxide level was significantly $(\mathrm{P}<0.05)$ decreased by $20.4 \%$ compared to rotenone-treated mice. Nitric oxide level was markedly $(\mathrm{P}<0.05)$ decreased by $24.1 \%$ in relation to rotenone-treated group after indomethacin administration at a dose of $(10 \mathrm{mg} / \mathrm{kg})$. However, nitric oxide level was not significantly $(\mathrm{P}>0.05)$ affected compared to rotenone induced changes after treatment with indomethacin $(10 \mathrm{mg} / \mathrm{kg})$ combined with vitamin $\mathrm{C}(25 \mathrm{mg} / \mathrm{kg})$, but was still significant $(\mathrm{P}<0.05)$ from vehicle-treated control value. After nimesulide administration at a dose of $(10 \mathrm{mg} / \mathrm{kg})$ nitric oxide level was not markedly $(\mathrm{P}>0.05)$ affected compared to rotenone induced changes, while was still significant $(\mathrm{P}<0.05)$ from vehicle-treated control group. After treatment with nimesulide $(10 \mathrm{mg} / \mathrm{kg})$ combined with vitamin C $(25 \mathrm{mg} / \mathrm{kg})$ nitric oxide level significantly $(\mathrm{P}<0.05)$ decreased by $36.8 \%$ relatively to rotenone-treated group (Figure 3).

\subsection{Acetylcholinesterase Activity}

In rotenone-treated mice $(1.5 \mathrm{mg} / \mathrm{kg})$ a significant $(\mathrm{P}<0.05)$ reduction in $\mathrm{AChE}$ level was observed by $26.2 \%$ relatively to vehicle-treated control group. AChE level was not restored $(\mathrm{P}>0.05)$ after 2 weeks recovery period from 
rotenone treatment compared to rotenone-treated mice. AChE level was highly $(\mathrm{P}<0.05)$ increased compared to rotenonetreated mice by $130.1 \%$ after the administration of indomethacin alone $(10 \mathrm{mg} / \mathrm{kg})$ and by $80.8 \%$ after the administration of indomethacin $(10 \mathrm{mg} / \mathrm{kg})$ combined with vitamin C (25 mg/kg). AChE level after administration of indomethacin $(10 \mathrm{mg} / \mathrm{kg})$ to rotenone-treated mice was significant $(\mathrm{P}<0.05)$ from $\mathrm{AChE}$ level after administration of indomethacin $(10 \mathrm{mg} / \mathrm{kg})+$ vitamin $\mathrm{C}(25 \mathrm{mg} / \mathrm{kg})$. AChE level was markedly $(\mathrm{P}<0.05)$ increased by $63.1 \%$ after treatment with nimesulide alone at $(10 \mathrm{mg} / \mathrm{kg})$ and by $42.1 \%$ after treatment with nimesulide $(10 \mathrm{mg} / \mathrm{kg})$ combined with vitamin $\mathrm{C}(25 \mathrm{mg} / \mathrm{kg})$ in relation to rotenone-treated group (Figure 4).

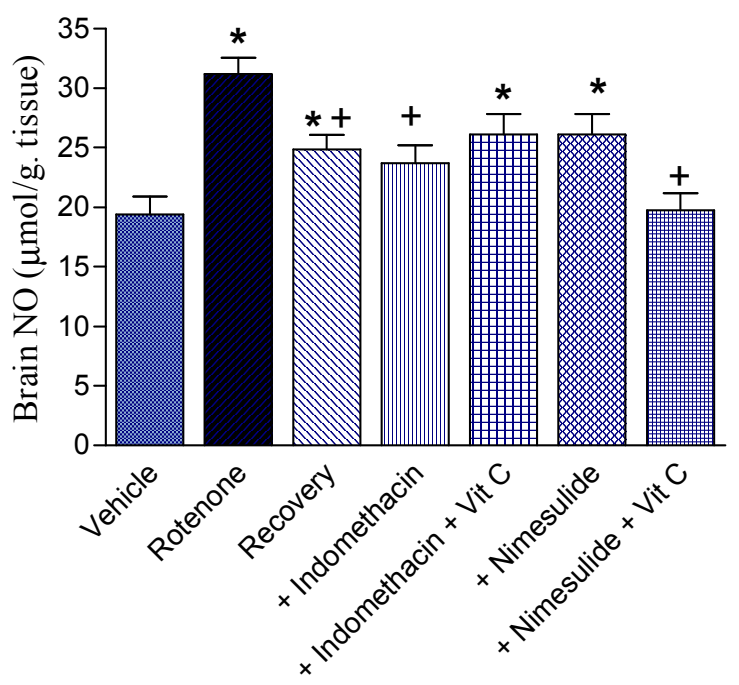

Figure. 3. Effect of treatment with indomethacin or nimesulide alone or combined with vitamin $C$ on nitrite in mice brain after rotenone treatment. $* P<0.05$ compared with the vehicle group. $+P<0.05$ compared with rotenone control group.

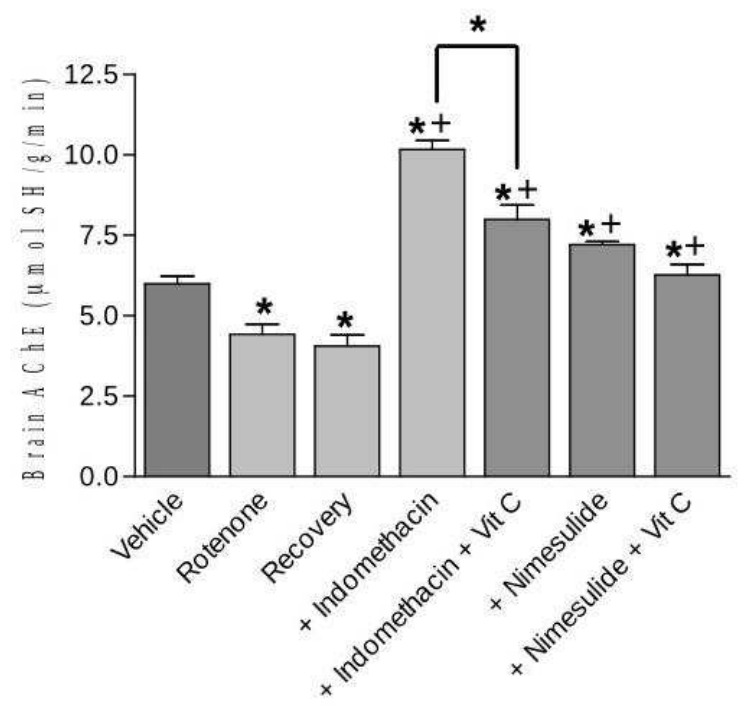

Figure 4. Effect of treatment with indomethacin or nimesulide alone or combined with vitamin $C$ on acetylcholiesterase activity in mice brain after rotenone treatment. $* P<0.05$ compared with the vehicle group. $+P<0.05$ compared with rotenone control group.

\subsection{Dopamine}

Rotenone administration induced significant $(\mathrm{P}<0.05)$ reduction of DA content in the mice brain by $14.8 \%$ in comparison to vehi cle- treated control group. After 2 weeks recovery period from rotenone treatment DA content was restored $(\mathrm{P}<0.05)$ by $47.8 \%$ in comparison to rotenonetreated mice. Treatment with indomethacin at $(10 \mathrm{mg} / \mathrm{kg})$ markedly $(\mathrm{P}<0.05)$ elevated DA content by $88.5 \%$ compared to rotenone-treated group. On the other hand, administration of indomethacin $(10 \mathrm{mg} / \mathrm{kg})$ combined with vitamin $\mathrm{C}(25$ $\mathrm{mg} / \mathrm{kg})$ caused significant $(\mathrm{P}<0.05)$ elevation to DA content by $68.3 \%$ relatively to rotenone- treated mice. Nimesulide administration at $(10 \mathrm{mg} / \mathrm{kg})$ significantly $(\mathrm{P}<0.05)$ elevated DA content by $60 \%$ compared to rotenone-treated mice, and administration of nimesulide $(10 \mathrm{mg} / \mathrm{kg})$ combined with vitamin C $(25 \mathrm{mg} / \mathrm{kg})$ markedly $(\mathrm{P}<0.05)$ increased DA content by $77.5 \%$ in relation to rotenone-treated group (Figure 5).

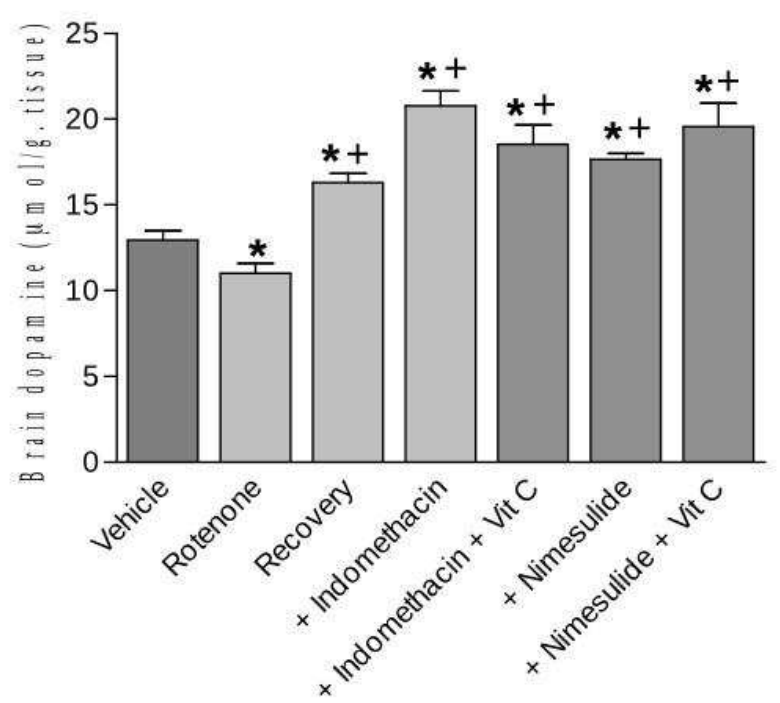

Figure 5. Effect of treatment with indomethacin or nimesulide alone or combined with vitamin $C$ on dopamine in mice brain after rotenone treatment. $* P<0.05$ compared with the vehicle group. $+P<0.05$ compared with rotenone control group.

\subsection{Norepinephrine}

After rotenone administration NE content was significantly $(\mathrm{P}<0.05)$ reduced by $15.3 \%$ in comparison to vehicle- treated control group. After 2 weeks recovery period from rotenone treatment $\mathrm{NE}$ content was significantly restored $(\mathrm{P}<0.05)$ by $45.1 \%$ in comparison to rotenone-treated mice. Treatment with indomethacin markedly $(\mathrm{P}<0.05)$ elevated $\mathrm{NE}$ level by $26.2 \%$ compared to rotenone-treated group. However, NE level did not alter $(\mathrm{P}>0.05)$ compared to rotenone-treated group after administration of indomethacin combined with vitamin $\mathrm{C}$, while was still significant $(\mathrm{P}<0.05)$ from vehicle group. NE content was not markedly affected $(\mathrm{P}>0.05)$ by nimesulide administration compared to rotenone-treated group, while was still significant $(\mathrm{P}<0.05)$ from vehicletreated control group. NE content also did not alter $(\mathrm{P}>0.05)$ 
after administration of nimesulide combined with vitamin $\mathrm{C}$ compared to rotenone induced changes (Figure 6).

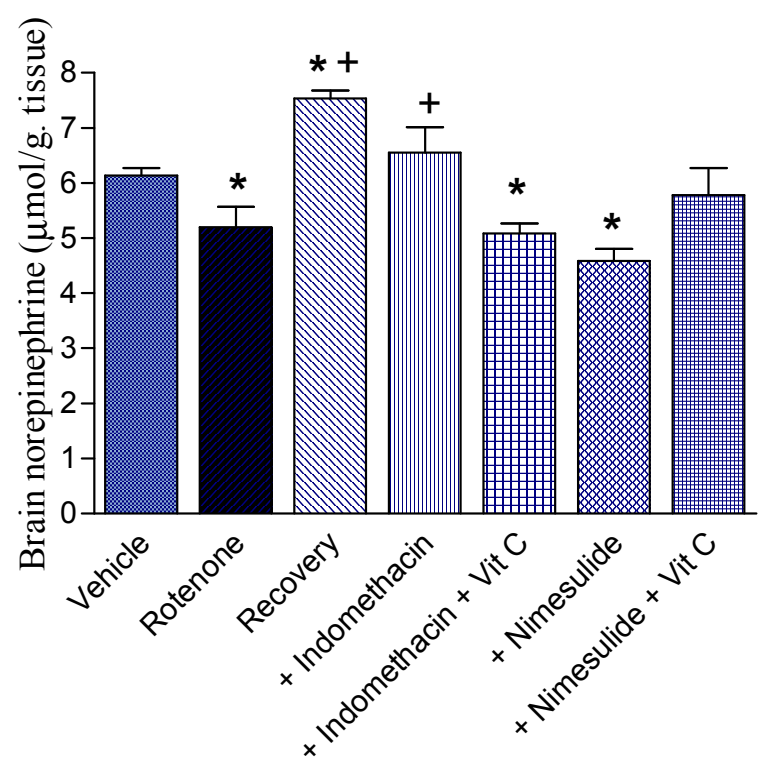

Figure 6. Effect of treatment with indomethacin or nimesulide alone or combined with vitamin $C$ on norepinephrine in mice brain after rotenone treatment. $* P<0.05$ compared with the vehicle group. $+P<0.05$ compared with rotenone control group.

\subsection{Serotonin}

Rotenone administration induced significant $(\mathrm{P}<0.05)$ reduction of 5 -HT content by $49.1 \%$ in comparison to vehicle- treated control group. 5-HT content was normalized $(\mathrm{P}<0.05)$ by $91.4 \%$, compared to rotenone-treated mice. Treatment with indomethacin markedly $(\mathrm{P}<0.05)$ elevated 5HT by $49.1 \%$ compared to rotenone-treated group. On the other hand, administration of indomethacin with vitamin $\mathrm{C}$ caused significant $(\mathrm{P}<0.05)$ elevation to 5 -HT level by $42.2 \%$ relatively to rotenone- treated mice. 5-HT level was significantly $(\mathrm{P}<0.05)$ elevated by $29.3 \%$ compared to rotenone-treated mice after nimesulide administration. Aministration of nimesulide combined with vitamin $\mathrm{C}$ markedly $(\mathrm{P}<0.05)$ increased 5 -HT content by $45.7 \%$ in relation to rotenone-treated group (Figure 7).

\subsection{Motor Activity}

In order to assess skilled reaching, mice were placed at bottom of a stair ( $30 \mathrm{~cm}$ in length) placed at an angle of $55^{\circ}$ above the bench and the latency of climbing the stair was recorded for three trials for each mouse. The time spent by mice to ascend a stair inclined to a $55^{\circ}$ angle was markedly $(\mathrm{P}<0.05)$ increased by $123.6 \%$ after rotenone administration $(1.5 \mathrm{mg} / \mathrm{kg})$ compared to vehicle-treated control value. The administration of indomethacin alone $(10 \mathrm{mg} / \mathrm{kg})$ or indomethacin $(10 \mathrm{mg} / \mathrm{kg})$ combined with vitamin $\mathrm{C}$ (25 $\mathrm{mg} / \mathrm{kg}$ ) to rotenone-treated mice resulted in significant $(\mathrm{P}<0.05)$ decrease in the time to ascend by $45 \%$ and $39.3 \%$ respectively, compared to rotenone only-treated group. Meanwhile, nimesulide alone $(10 \mathrm{mg} / \mathrm{kg})$ or nimesulide $(10$ $\mathrm{mg} / \mathrm{kg})$ combined with vitamin $\mathrm{C}(25 \mathrm{mg} / \mathrm{kg})$ treated mice exhibited significant $(\mathrm{P}<0.05)$ decreases in the time to ascend by $16.4 \%$ and $17.1 \%$ respectively, in comparison to rotenone only-treated group (Figure 8).

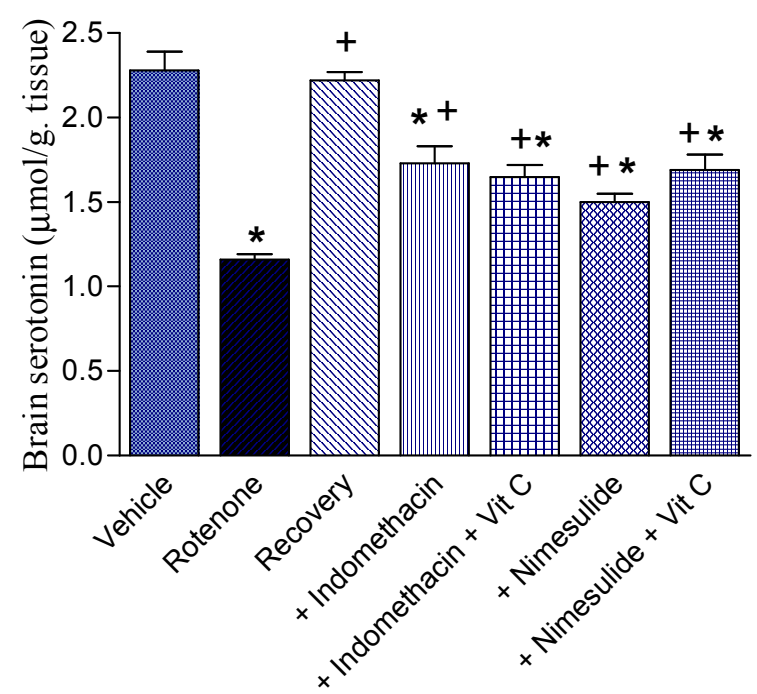

Figure 7. Effect of treatment with indomethacin or nimesulide alone or combined with vitamin $C$ on serotonin in mice brain after rotenone treatment. ${ }^{*} P<0.05$ compared with the vehicle group. $+P<0.05$ compared with rotenone control group.

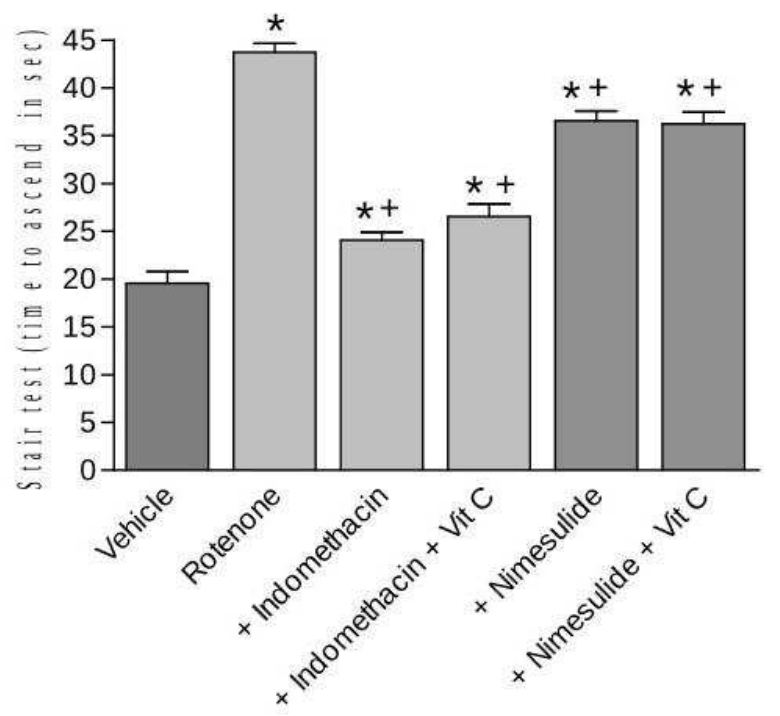

Figure 8. Effect of treatment with indomethacin or nimesulide alone or combined with vitamin $C$ on the time to ascend (sec) in the stair test after rotenone treatment. Columns represent the mean of three consecutive measurements. $* P<0.05$ compared with the vehicle group. $+P<0.05$ compared with rotenone control group.

\subsection{Histopathological Results}

\subsubsection{Cortex}

The histological study of the control brains showed normal cellularity and round nuclei of the cerebral cortex (Figure 9A). Histopathological changes of the cerebral cortex of rotenone treated mice included cellular infiltration, atrophy, pyknosis, necrosis, congestion of cerebral blood vessels, as 
well as focal gliosis. Perinuclear cytoplasmic vacuoles were observed (Figure $9 \mathrm{~B}$ ). The most prominent observations of the examined sections of mice treated with rotenone and indomethacin were atrophy, pyknosis, shrunken cells and hemorrhage as well as fragmentation and condensation of the nuclei compared to control. Perinuclear cytoplasmic vacuoles and focal gliosis were also noted (Figure $9 \mathrm{C}$ ). However, in the group treated with rotenone, indomethacin and vitamin C, there were milder alterations such as perinuclear cytoplasmic vacuoles in neurons and pyknotic nuclei (Figure 9 D). Mice treated with nimesulide exhibited degenerated neurons in cortex which appeared shrunken with pyknotic nuclei and vacuolation. Hemorrhage were also observed (Figure 9 E). Sections from mice treated with rotenone + nimesulide + vitamin $\mathrm{C}$ displayed preservation of most of the neurons with an almost normal appearance. Few cells only were seen affected (Figure $9 \mathrm{~F}$ ).

\subsubsection{Striatum}

The histological study of the control brains showed normal neurons with normal nuclei and prominent nucleoli (Figure $10 \mathrm{~A})$. In group treated with rotenone, degenerated neurons appeared shrunken with dark cytoplasm and pyknotic nuclei. Pericellular vacuolation of the neurons and presence of eosinophilic lesions and hemorrhage were also observed (Figure $10 \mathrm{~B}$ ). Sections from mice treated with rotenone and indomethacin revealed extensive neuronal damage. Neurons appeared smaller and shrunken compared to the control section. Vacuolations were also observed (Figure $10 \mathrm{C}$ ). In contrast, the brain of mice treated with rotenone, indomethacin and vitamin $\mathrm{C}$ showed attenuated histopathological changes except pyknosis of some neurons (Figure 10 D). On the other hand, sections from mice administered rotenone and nimesulide still showed marked degeneration indicated by decreased cell size, vacuolations, and hypercromatic cells with congested capillaries (Figure 10 E). These changes were, however, attenuated after treatment with vitamin $C$, except few cells that were seen affected (Figure $10 \mathrm{~F}$ ).

\subsubsection{Hippocampus}

The hippocampus from the control mice showed pyramidal cells of normal appearance (Figure $11 \mathrm{~A})$. The hippocampus of rotenone-treated mice showed pyknosis of pyramidal cells (Figure $11 \mathrm{~B}$ ). This tissue damage increased following the administration of both rotenone, indomethacin (Fig.11 C) but attenuated in mices treated with indomethacin and vitamin $\mathrm{C}$ (Figure 11 D). Pyknosis of pyramidal cells was also seen in mice treated with rotenone and nimesulide (Figure $11 \mathrm{E}$ ). In contrast, in mice treated with vitamin $\mathrm{C}$, along with nimesulide and rotenone,there was decreased neuronal degeneration with only few neuronal cells showing pyknosis (Figure $11 \mathrm{~F}$ ).

\section{Discussion}

In the present investigation we aimed at comparing between the effects of the non-selective COX inhibitor indomethacin and the selective COX-2 inhibitor nimesulide on a rotenone-induced PD animal model, where each drug was given alone or combined with vitamin $\mathrm{C}$. The findings of the present study provide evidence that treatment with indomethacin or nimesulide each administered alone or combined with vitamin $\mathrm{C}$ can decrease many biochemical changes evoked by rotenone, a pesticide and complex I inhibitor, in mice. Rotenone is widely used to induce experimental models of PD through different routes and doses of administration [47]. Continuous administration of rotenone in rats causes nigrostriatal dopaminergic loss, formation of cytoplasmic inclusions containing $\alpha$-synuclien ( $\alpha$-syn) resembling Lewy bodies (LBs) that found in humans with PD and behavioral symptoms of PD including decreased locomotion, flexed posture, and rigidity [57].

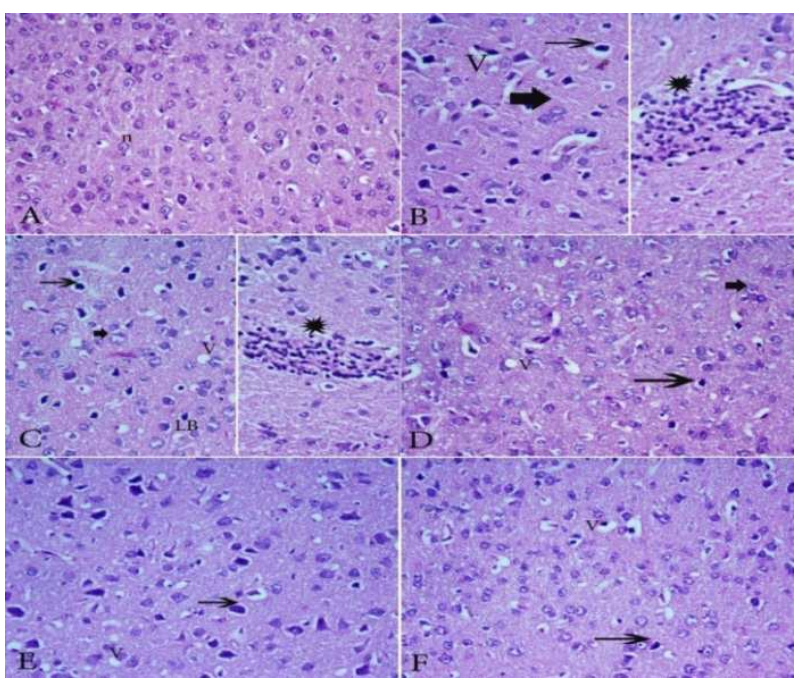

Figure 9. Hematoxylin and eosin-stained sections of mice cerebral cortex after treatment with: (A) Vehicle. (B) Rotenone. (C) Rotenone+ indomethacin. (D) Rotenone+ indomethacin + vitamin C. (E) Rotenone+ nimesulide. $(F)$ rotenone + nimesulide + vitamin $C$.

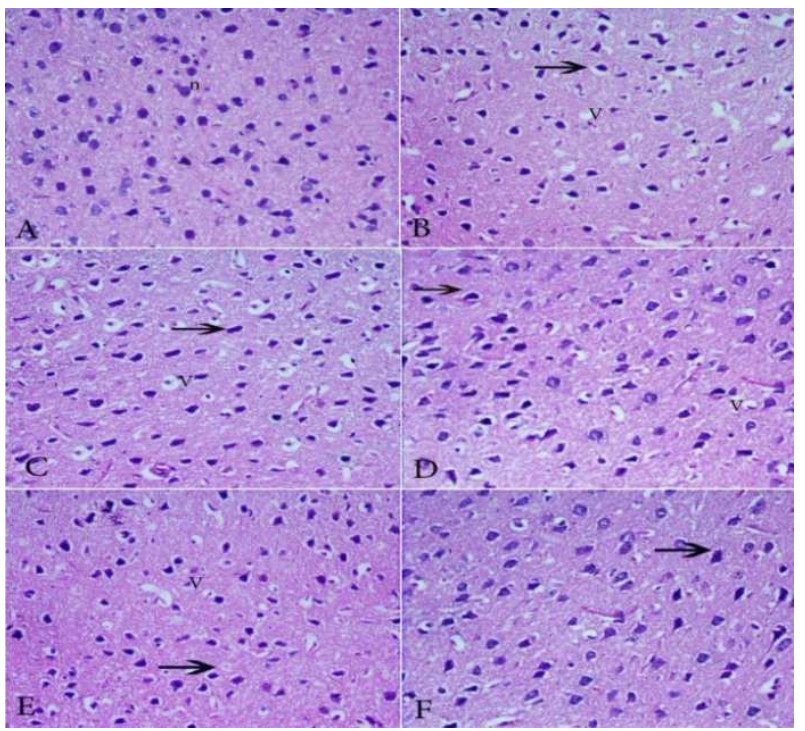

Figure 10. Hematoxylin and eosin-stained sections of mice striatum after treatment with: (A) Vehicle. (B) Rotenone. (C) Rotenone+ indomethacin. (D) Rotenone+ indomethacin + vitamin C. (E) Rotenone+ nimesulide. (F) rotenone + nimesulide + vitamin $C$. 


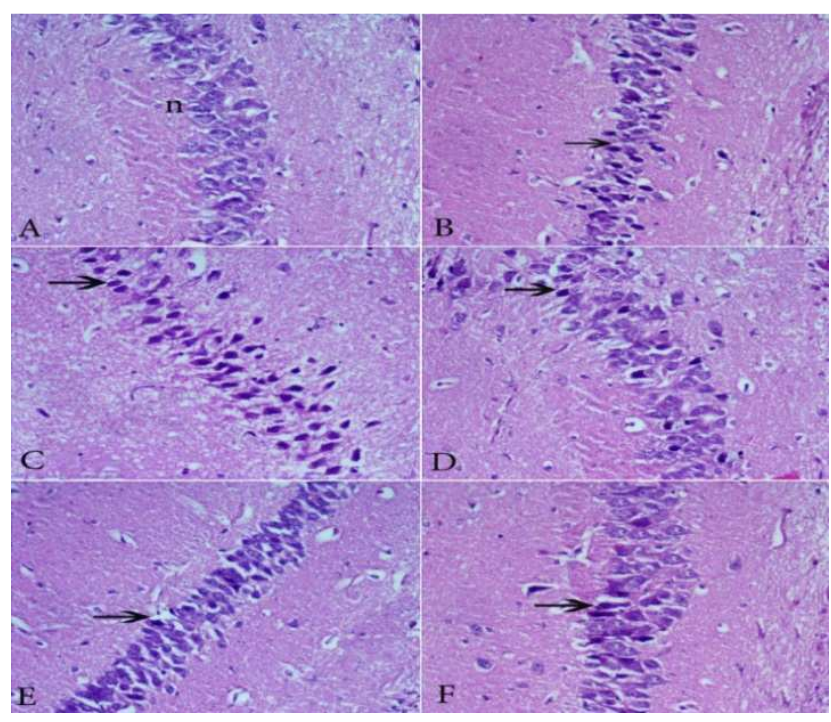

Figure 11. Hematoxylin and eosin-stained sections of mice Hippocampus after treatment with: (A) Vehicle. (B) Rotenone. (C) Rotenone+ indomethacin. (D) Rotenone+ indomethacin+ vitamin C. (E) Rotenone+ nimesulide. $(F)$ rotenone + nimesulide + vitamin $C$.

In the present study it was found that subcutaneous administration of rotenone in mice induced several features of PD including reduction of DA concentration, nigrostriatal degeneration, increase in the oxidative stress indices and impairment of motor performance expressed in stair test. Strong evidence supports the role of increased oxidative stress and mitochondrial dysfunction in the pathogenesis of PD [14, 58]. Inhibition of mitochondrial complex I by rotenone treatment may also induce the production of reactive oxygen species [59]. Several studies found that MDA levels are increased in brain of rotenone treated animals compared to vehicle treated animals [60]. Administration of rotenone caused depletion of GSH in rat brains [61]. Microglia are activated by rotenone administration and once activated by rotenone, microglial cells increase the generation of reactive oxygen species [62]. In the present work, subcutaneous injection of rotenone caused increased oxidative stress in the whole brain as shown by significant reduction of GSH in brain and significant increase of malondialdehyde (MDA) which is a marker of lipid peroxidation. MDA production reflects oxidative damage of lipids [63]. MDA indicates increased free radical production attack on membrane lipids [64]. The level of nitric oxide also was elevated in the brain after rotenone treatment. Production of nitric oxide is a marker of oxidative stress [18]. Elevated nitric oxide levels were detected in brains of rotenone-treated mice [60]. Nitric oxide plays a key role in rotenone-induced nigrostriatal injury in rats, as chronic rotenone administration caused significant injury to the nigrostriatal system which mediated by increased generation of nitric oxide [48]. High levels of nitric oxide inhibit respiratory chain complexes by peroxynitrite (ONOO-) that formed by superoxide anion $\left(\mathrm{O}^{2-}\right)$ and nitric oxide (NO) [65]. Reduced glutathione (GSH) is one of the most important antioxidants in the brain that plays an important role in the prevention of oxidative stress and protecting cells from oxidative damage [66]. Reduction of the GSH level in the brain is correlated to the increase in oxidative stress induced by rotenone. The excess production of free radicals leads to consumption of GSH, the scavenger molecule. The effects of rotenone on oxidative stress in the brain were reduced by coadministration of indomethacin or iinimesulide alone or combined with vitamin C. Thus, indomethacin alone or nimesulide combined with vitamin $\mathrm{C}$ resulted in significant reduction of nitric oxide level, while indomethacin combined with vitamin $\mathrm{C}$ or nimesulide alone caused significant decrease in MDA level, and the GSH content was markedly elevated after administration of each drug alone or combined with vitamin $\mathrm{C}$, suggesting decreased oxidative and nitrosative stress on administration of the drugs.

NSAIDs in general are considered to be beneficial by inhibiting COX enzyme, scavenging reactive oxygen and nitrite radicals and inhibiting the activation of TNF $\alpha$ [67]. Different types of studies were conducted for evaluating antiparkinson activities of Indomethacin. Indomethacin can protect the complex-I enzymes and increase the efficacy of the neuronal mitochondria [68]. It has an ability to scavenge NO radicals [69]. It was shown that nimesulide has therapeutic potential in treatment of PD and it was shown to evaluate neuroprotective effect. Moreover it was reported that chronic administration of nimesulide ( 5 or $10 \mathrm{mg} / \mathrm{kg}$ ) attenuated the alterations induced by MPTP in the animal brains of a PD model and inhibited the oxidative stress induced by MPTP [70]. It was suggested that during oxidative stress induced by the toxin, glutathione peroxidase which is responsible for scavenging hydrogen peroxide radicals under normal conditions is not enough to attenuate the oxidative alterations, so the level of oxidized glutathione (GSSG) elevates by continuous administration of the cellular toxin and so the redox state of the DA neurons is altered. Treatment of nimesulide restored the antioxidant enzymes and normalized the redox state [70].

In the present study, subcutaneous administration of rotenone in mice resulted in a significant reduction of brain dopamine content. Our results are also supported by other data obtained using rotenone as an experimental PD model $[47,71,72]$. Because of the ability of rotenone to freely enter all cells, the high susceptibility of the dopaminergic neurons to rotenone suggested that dopaminergic neurons are sensitive to complex I inhibition [47]. DA degeneration mainly entails formation of reactive species, so additional oxidative stress caused by microglial activation, increases the vulnerability of the nigrostriatal dopaminergic neurons to the oxidative damage [73]. DA metabolism produces hydrogen peroxide and superoxide radicals, and auto-oxidation of DA produces quinine products [74]. Oxidative stress causes oxidation of DA to quinone products that cause damage to the mitochondria of the brain [75]. The formation of the potent oxidant peroxynitrite which is produced by the interaction between ROS especially supeoxide with NO [76] may directly oxidize DA [75] and lead to damage of dopaminergic neurons [78]. On the other hand, 
administration of indomethacin alone or combined with vitamin $C$ resulted in a marked increase in the DA level in the brain. NSAIDs in general have been shown to reduce dopaminergic neuron degeneration in animal models of PD [35]. Results from animal models of PD displayed that indomethacin has the ability to prevent MPTP-induced loss of striatal DA in mice like those of Kurkowska-Jastrzebska et al. (2002) [41] who used MPTP-induced mice as a PD model and they found that treatment with indomethacin at a dose of $1 \mathrm{mg} / \mathrm{kg}$ protects against MPTP-induced neural damage of dopaminergic neurons and they demonstrated that this effect is associated with diminished microglial activation in the damaged areas. Pathology of PD involves neuroinflammatory processes including increased expression of $\mathrm{COX}$ and elevated prostaglandin E2 (PGE2) levels [79]. Generally, the ability of NSAIDs to suppress inflammation is based on their ability to inhibit the COX enzyme [33]. Indomethacin inhibits COX by inhibiting PG synthesis, so it was suggested that the neuroprotective activity of indomethacin depends on PG inhibition [68].

We also found that nimesulide administered alone elevated the DA level in the mice brain. Increased DA level indicated that antioxidant effect of nimesulide might be responsible for inhibiting the oxidation of DA which induced by rotenone treatment. Nimesulide might have prevented the mitochondrial dysfunction and oxidative stress induced by rotenone and thus prevented the inhibition of the cell damaging pathways by inhibiting the inflammatory mediators according to its selective inhibition of COX-2.

In the present investigation, subcutaneous rotenone administration induced a marked reduction of the NE level in the brain. This result is consistent with those of AbdelRahman et al. (2008) [80]. We also found that rotenone administration significantly decreased the 5-HT level in the brain, a result that goes in line with those of He et al. (2003) [48] and Verma and Nehru (2009) [60] who also used rotenone treatment. it was revealed that rotenone causes a multisystem degeneration incorporating 20-30\% losses in the striatum of serotonergic fibers and about $30 \%$ loss of noradrenergic neurons in the locus coeruleus and substantia nigra pars compacta (SNpc) cells [71]. Degenerations of NE neurons of the locus coeruleus and 5-HT neurons of the dorsal raphe are considered as pathological changes in PD [81]. The cognitive and behavioral impairments observed in PD suggest a role of the 5-HTand NE systems [82]. Our results revealed that the levels of NE and 5-HT were also elevated by administration of indomethacin alone while its combination with vitamine $\mathrm{C}$ did not improve its action. Treatment with nimesulide caused elevation of 5-HT content in the brain and combination with vitamin $\mathrm{C}$ did not improve the action of nimesulide. Nimesulide neither administered alone nor combined with vitamin $\mathrm{C}$ has a significant effect on $\mathrm{NE}$ level in the mice brain. The rise of NE is directly linked to the elevation of DA levels, as the increased availability of DA as a precursor of NE, enhanced the synthesis of the latter, as displayed in our investigation after treatment with indomethacin in the roteone-treated mice.
In the current investigation, AChE activity was markedly reduced in the mice brain after administration of rotenone, a result that goes in line with those of Zhang et al. (2013) [83], who used MPTP-induced mice as a model of PD. In vivo studies of AChE have been shown cholinergic projection losses in the magnitude of $5 \%$ to $25 \%$ in PD subjects [84]. Cholinergic degeneration may play a key role in the cognitive decline in PD [85]. AChE has been regarded as a reliable marker for brain cholinergic pathways in the human brain [86]. The enzyme AChE is responsible for degrading acetylcholine (ACh) [87] which is the major neurotransmitter related to memory [88]. Administration of the drugs, indomethacin and nimesulide alone or combined with vitamin $\mathrm{C}$ resulted in a marked elevation in the activity of $\mathrm{AChE}$ in the mice brain.

In our histological results it was obvious that indomethacin alone did not decrease the injury of the neurons and nimesulide alone did not markedly attenuate the neuronal injury, but the interesting finding is that vitamin $\mathrm{C}$ combination significantly protected the neurons and attenuated the neuronal injury in the striatum, hippocampus and cortex. Vitamin C (ascorbic acid) at low doses is an exogenous powerful antioxidant molecule which acts with endogenous antioxidant systems within tissue cells to scavenge the formed ROS [89]. The Presence of vitamin C as an antioxidant in the different brain regions makes the brain tissue susceptible to oxidative attack [90]. It was reported that administration of vitamin $\mathrm{C}$ to systemically injected MPTP mice increased the striatal DA level [91].

In the current study, the stair test was used for assessment of the skilled reaching and evaluating the motor performance. We found that rotenone treatment caused a marked increase of the time spent by mice to ascend the stair which inclined to a $55^{\circ}$ angle, and we concluded that it reflected the slowness of movement (bradykinesia) as a main feature of $\mathrm{PD}$ that induced by rotenone administration. According to Betarbet et al. (2000) [47], rotenone-treated animals exhibited motor and postural deficits characteristic of PD and all animals with a dopaminergic lesion became hypokinetic and had unsteady movement. They concluded that rotenone may act via the inhibition of mitochondrial complex I leading to selective damage of the DA neurons associated with the PD motor and postural deficits. Motor functions impairment is correlated to deficiency of DA [92] as DA deficiency in the striatum is associated clinically with motor symptoms of PD including bradykinesia, tremor, rigidity and postural instability [4]. In the basal ganglia one of the mechanisms leading to motor changes is the balance between cholinergic and dopaminergic systems, as Ach and DA play a key role in the control of motor functions [93]. In the present study, rotenone treatment caused marked decrease in DA and reduction in $\mathrm{AChE}$ contents in the brain (increase $\mathrm{ACh}$ ), which resulted in imbalance between DA and ACh contents in the brain leading to impaired motor functions. The imbalance between DA and $\mathrm{ACh}$ is a consequence of excessive ACh concentrations as well as DA deficiency [94]. In the present investigation, the motor function of mice was 
markedly improved by administration of indomethacin or nimesulide, alone or combined with vitamin $\mathrm{C}$. The nonselective COX inhibitor and the selective COX-2 inhibitor significantly restored the motor activity. Thus according to our results we concluded that the antioxidant effect of both indomethacin and nimesulide might be responsible for inhibition of DA oxidation and prevented the motor impairments caused by rotenone treatment by restoring the normal balance between DA and NE in the brain.

In conclusion, our study revealed that non-selective inhibition of COX-1 and COX-2 by indomethacin and also selective inhibition of COX-2 by nimesulide is effective in decreasing oxidative stress (decrease MDA and NO, and increase GSH. On the other hand, selective COX-2 inhibition was effective in decreasing brain damage in rotenone-treated mice. Moreover, Vitamin $\mathrm{C}$ at low doses showed an additive effect when combined with either indomethacin or nimesulide both biochemically and histologically and so it can be used safely with NSAIDs in PD patients.

\section{References}

[1] Baba M, Nakajo S, Tu PH, Tomita T, Nakaya K, Lee VM, Trojanowski JQ, Iwatsubo T (Aggregation of alpha-synuclein in Lewy bodies of sporadic Parkinson's disease and dementia with Lewy bodies) Am. J. Pathol., 1998; 152, 879-884.

[2] Cicchetti F, Drouin-Ouellet J, Gross RE (Environmental toxins and Parkinson's disease: what have we learned from pesticide-induced animal models) Trends Pharmacol Sci., 2009; 30, 475-483.

[3] Marsden CD (Problems with long-term levodopa therapy for Parkinson's disease) Clin Neuropharmacol., 1994; 17, Suppl. 2, S32-S44.

[4] Tedroff JM (Functional consequences of dopaminergic degeneration in Parkinson's disease) Adv Neurol., 1999; 80: 67-70.

[5] Bonnet A, Houeto J (Pathophysiology of Parkinson's disease) Biomed Pharmacotherapy, 1999; 53 (3), 117-121.

[6] Sulzer D, Surmeier DJ (Neuronal vulnerability, pathogenesis and Parkinson's disease) Mov Disord., 2013; 28, 715-724.

[7] Politis M, Loane C (Serotonergic Dysfunction in Parkinson's Disease and Its Relevence to Disability) Scientific World Journal, 2011; 11, 1726-1734.

[8] Halliday GM, Li YW, Blumbergs PC, Joh TH, Cotton RG, Howe PR, Blessing WW, Geffen LB (Neuropathology of immunohistochemically identified brainstem neurons in Parkinson's disease) Ann Neurol., 1990; 27: 373-85.

[9] Sherer TB, Betarbet R, Greenamyre JT (Environment, mitochondria, and Parkinson's disease) Neuroscientist, 2002; 8: $192-197$.

[10] Tanner CM, Kamel F, Ross GW, Hoppin JA, Goldman SM, Korell M, Marras C, Bhudhikanok GS, Kasten M, Chade AR, Comyns K, Richards MB, Meng C, Priestley B, Fernandez HH, Cambi F, Umbach DM, Blair A, Sandler DP, Langston JW (Rotenone, paraquat, and Parkinson's disease) Environ Health Perspect., 2011; 119 (6), 866-872.
[11] Wang A, Costello S, Cockburn M, Zhang X, Bronstein J, Ritz B (Parkinson's disease risk from ambient exposure to pesticides) Eur J Epidemiol., 2011; 26(7): 547-555.

[12] Lev N, Melamed E. (Heredity in Parkinson's disease: new findings) Isr Med Assoc J., 2001; 3, 435.

[13] Di Monte DA, Lavasani M, Manning-Bog AB (Environmental factors in Parkinson's disease) Neurotoxicology., 2002; 23(45):487-502.

[14] Schapira AH (Mitochondria in the aetiology and pathogenesis of Parkinson's disease) Lancet Neurol., 2008; 7:97-109.

[15] Moldovan L, Moldovan NI (Oxygen free radicals and redox biology of organelles) Histochemistry and Cell Biology, 2004; vol. 122 , no. 4, pp. 395-412.

[16] Turrens JF (Superoxide production by the mitochondrial respiratory chain) Biosci Rep., 1997; 17(1), 3-8.

[17] Facchinetti F, Dawson VL, Dawson TM (Free radicals as mediators of neuronal injury) Cell Mol Neurobiol., 1998; 18:667-682.

[18] Halliwell B. (Free radicals and antioxidants - quo vadis) Trends Pharmacol Sci., 2011; 32, 125-130.

[19] Moncada S. (Nitric oxide in the vasculature: physiology and pathophysiology) Ann N Y Acad Sci., 1997; 811:60-67.

[20] Saran M, Michel C, Bors W. (Reaction of NO with $\mathrm{O}^{\circ} 2-$. Implications for the action of endothelium-derived relaxing factor (EDRF)) Free Radic Res Commun., 1990; 10:221-6.

[21] Agil A, Duran R, Barrero F, Morales B, Arauzo M, Alba F (Plasma lipid peroxidation in sporadic Parkinson's disease. Role of the L-dopa) J Neurol Sci., 2006; 240, 31-36.

[22] Alam Z, Daniel S, Lees A, Marsden D, Jenner P, Halliwell B (A generalised increase in protein carbonyls in the brain in Parkinson's but not incidental Lewy body disease) J Neurochem., 1997; 69, 1326-1329.

[23] Dringen R (Metabolism and functions of glutathione in brain) Prog Neurobiol., 2000; 62:649-671.

[24] Floor E, Wetzel MG (Increased protein oxidation in human substantia nigra pars compacta in comparison with basal ganglia and prefrontal cortex measured with an improved dinitrophenylhydrazine assay) J Neurochem., 1998; 70:268275 .

[25] Przedborski S, Jackson-Lewis V (ROS and Parkinson's disease: a view to a kill. In Free Radicals in Brain Pathophysiology) G. Poli, E. Cadenas, and L. Packer, eds. New York: Marcel Dekker, niInc., 2000; pp. 273-290.

[26] Sánchez-Pernaute R, Ferree A, Cooper O, Yu M, Brownell A, Isacson $\mathrm{O}$ (Selective COX-2 inhibition prevents progressive dopamine neuron degeneration in a rat model of Parkinson's disease) Journal of Neuroinflammation, 2004; 1:6.

[27] Hirsch EC, Hunot S, Hartmann A. (Neuroinflammatory processes in Parkinson's disease) Parkinsonism Relat Disord., 2005; 11 (Supp1 1): S9-S15.

[28] Schulte T, Schols L, Muller T, Woitalla D, Berger K, Kruger R. (Polymorphisms in the interleukin-1 alpha and beta genes and the risk for Parkinson's disease) Neurosci Lett., 2002; 326:70-72. 
[29] Vane JR, Botting RM (Anti-inflammatory drugs and their mechanism of action) Inflamm Res., 1998; 47 (suppl 2): S78S87.

[30] O'Banion MK (Cyclooxygenase-2: molecular biology, pharmacology, and neurobiology) Crit. Rev. Neurobiol., 1999; $13,45-82$.

[31] Flower RJ (The development of COX2 inhibitors) Nat Rev Drug Discov., 2003; 2, 179-191.

[32] Laurence L, Brunton J, John S, Keit L, editors (Non-dteroidal anti-inflammatory drugs) McGraw Hill. Goodman and Gill's. The pharmacological basis of therapeutics, 2006; pp. 673-706.

[33] Vane JR (Inhibition of prostaglandin synthesis as a mechanism of action for aspirin-like drugs) Nature (London), 1971; 231, 232-235.

[34] Regula J, Butruk E, Dekkers CP, de Boer SY, Raps D, Simon L, Terjung A, Thomas KB, Luhmann R, Fischer R (Prevention of NSAID-associated gastrointestinal lesions: a comparison study pantoprazole versus omeprazole) Am. J. Gastroenterol., 2006; 101 (8), 1747-1755.

[35] Chen H, Zhang SM, Hernán MA, Schwarzschild MA, Willett WC, Colditz GA, Speizer FE, Ascherio A (Nonsteroidal antiinflammatory drugs and the risk of Parkinson disease) Arch Neurol., 2003; 60 (8): 1059-64.

[36] Chen H, Jacobs E, Schwarzschild MA, McCullough ML, Calle EE, Thun MJ, Ascherio A (Nonsteroidal antiinflammatory drug use and the risk for Parkinson's disease) Ann Neurol., 2005; 58: 963-967.

[37] Herna'n MA, Logroscino G, García Rodríguez LA (Nonsteroidal anti-inflammatory drugs and the incidence of Parkinson disease) Neurology, 2006; 66:1097-1099.

[38] Manthripragada AD, Schernhammer ES, Qiu J, Friis S, Wermuth L, Olsen JH, Ritz B (Non-steroidal antiinflammatory drug use and the risk of Parkinson's disease) Neuroepidemiology, 2011; 36 (3): 155-61.

[39] Becker CJick SS Meier CR (NSAID use and risk of Parkinson disease: a population-based case-control study) Eur J Neurol., 2011; 18 (11): 1336-42.

[40] Hardman JG, Limbird LE, Gilman AG. Goodman and Gilman's (The Pharmacological Basic of Therapeutics) 10th International Edition, The McGraw-Hill Companies Inc., 2001.

[41] Kurkowska-Jastrzebska I, Babiuch M, Joniec I, Przybylkowski A, Czlonkowski A, Czlonkowska A (Indomethacin protects against neurodegeneration caused by MPTP intoxication in mice) Int. Immunopharmacol., 2002; 2, 1213-1218.

[42] Hawboldt J (Adverse events associated with NSAIDs) US Pharm., 2008; 33 (12): HS5-HS13.

[43] Kataoka H, Horie Y, Koyama R, Nakatsugi S, Furukawa M (Interaction between NSAIDs and steroid in rat stomach: safety of nimesulide as a preferential COX-2 inhibitor in the stomach) Dig Dis Sci., 2000; 45, 1366-1375.

[44] Chandra J, Bhatnagar SK (Antipyretics in children) Indian J Pediatr., 2002; 69, 69-74.

[45] Dhir A, Naidu PS, Kulkarni SK (Neuroprotective effect of nimesulide, a preferential COX-2 inhibitor, against pentylenetetrazol (PTZ)-induced chemical kindling and associated biochemical parameters in mice) Seizure, 2007; 16, 691.

[46] Wang Y, Deng XL, Xiao XH, Yuan BX (A non-steroidal antiinflammatory agent provides significant protection during focal ischemic stroke with decreased expression of matrix metalloproteinases) Curr Neurovasc Res., 2007; 4, 176.

[47] Betarbet R, Sherer TB, MacKenzie G, Garcia-Osuna M, Panov A, Greenamyre T (Chronic systemic pesticide exposure reproduces features of Parkinson's disease. nature neuroscience) volume 3 no 12, 2000.

[48] He Y, Imam SZ, Dong Z, Jankovic J, Ali SF, Appel SH, Le W (Role of nitric oxide in rotenone-induced nigro-striatal injury) Journal of Neurochemistry, 2003; 86, 1338-1345.

[49] Ruiz-Larrea MB, Leal AM, Liza M, Lacort M, de Groot H. (Antioxidant effects of estradiol and 2-hydroxyestradiol on iron induced lipid peroxidation of rat liver microsomes) Steroids, 1994; 59 (6): 383-388.

[50] Ellman GL (Tissue sulfhydryl groups) Arch Biochem., 1959; 82 (1): 70-77.

[51] Moshage H, Kok B, Huizenga JR, Jansen PL (Nitrite and nitrate determination in plasma: a critical evaluation) Clin Chem., 1995; 41 (6 Pt 1): 892-896.

[52] Ellman GL, Courtney KD, Andres V Jr, Feather-Stone RM (A new and rapid colorimetric determination of acetylcholinesterase activity) Biochem Pharmacol., 1961; 7: 88-95.

[53] Gorun V, Proinov I, Baltescu V, Balaban G, Barzu O (Modified Ellman procedure for assay of cholinesterases in crude enzymatic preparation) Anal Biochem., 1978; 86 (1): 324-326.

[54] Ciarlone AE (Further modification of a fluoremetric method for analyzing brain amines) Microchem. J., 1978; 23: 9-12.

[55] Shore PA, Olin JS (Identification and chemical assay of norepinephrine in brain and other tissues) J Pharmacol EXP Ther., 1958; 122 (3): 295-300.

[56] Baird AL, Meldrum A, Dunnett SB (The staircase test of skilled reaching in mice) Brain Res Bull., 2001; 54: 243-250.

[57] Sherer TB, Betarbet R, Testa CM, Seo BB, Richardson JR, Kim JH, Miller GW, Yagi T, Matsuno-Yagi A, Greenamyre JT (Mechanism of toxicity in rotenone models of Parkinson's disease) J Neurosci., 2003; 23: 10756-64.

[58] Beal MF (Mitochondria and neurodegeneration) Novartis Found Symp., 2007; 287: 183-192.

[59] Hensley K, Pye QN, Maidt ML, Stewart CA, Robinson KA, Floyd RA (Interaction of alpha-phenyl-N-tert-butyl nitrone and alternative electron acceptors with complex 1 indicates a substrate reduction site upstream from the rotenone binding site). J. Neurochem., 1998; 71, 2549-2557.

[60] Verma R, Nehru B (Effect of centrophenoxine against rotenone-induced oxidative stress in an animal model of Parkinson's disease). Neurochem Int., 2009; 55 (6): 369-75.

[61] Xiong N, Huang J, Zhang Z, Zhang Z, Xiong J (Stereotaxical Infusion of Rotenone: A Reliable Rodent Model for Parkinson's Disease) PLoSONE, 2009; 4 (11), e7878. 
[62] Chang CY, Song MJ, Jeon SB, Yoon HJ, Lee DK, Kim IH, Suk K, Choi DK, Park EJ ( Dual functionality of myeloperoxidase in rotenone-exposed brain-resident immune cells) Am J Pathol., 2011; 179 (2): 964-979.

[63] Esterbauer H, Schaur JS, Zollner H. (Chemistry and biochemistry of 4- hydroxynonenal, malonaldehyde and related aldehydes) Free Radic Biol Med., 1991; 11: 81-128.

[64] Gutteridge JM (Lipid peroxidation and antioxidants as biomarkers of tissue damage) Clin Chem., 1995; 41 (12 Pt 2): $1819-1828$

[65] Murray, J., Taylor, S. W., Zhang, B., Ghosh, S. S., Capaldi, R. A. (2003). Oxidative damage to mitochondrial complex I due to peroxynitrite; Identification of reactive tyrosines by Mass spectrometry. J Biol Chem. 278 (39): 37223-30.

[66] Vali S, Mythri R, Jagatha B, Padiadpu J, Ramanujan K, Andersen J. (Integrating glutathione metabolism and mitochondrial dysfunction with implications for Parkinson's Disease: a dynamic model) Neurosci., 2007; 149, 917-930.

[67] Asanuma M, Miyazaki I. (Nonsteroidal anti-inflammatory drugs in experimental parkinsonian models and Parkinson's disease) Curr Pharm., 2008; 14: 1428 -1434.

[68] Antony S, Gudluru S, Pal B, Vadivelan R, Kumar MN, Elango $\mathrm{K}$, Suresh B (Indomethacin, nifedipine and its combination produced anti-Parkinson's activity in 6-OHDA lesioned rat model) Pharmacie Globale (IJCP), 2010; 4 (05).

[69] Asanuma M, Nishibayashi-Asanuma S, Miyazaki I, Kohno M, Ogawa N. (Neuroprotective effects of non-steroidal antiinflammatory drugs by direct scavenging of nitric oxide radicals) J Neurochem., 2001; 76: 1895-904.

[70] Gupta A, Dhir A, Kumar A, Kulkarni SK (Effect of preferential cyclooxygenase-2 (COX-2) inhibitor against 1methyl-4 phenyl-1, 2, 3-tertahydropyridine (MPTP)-induced striatal lesions in rats: Behavioral, biochemical and histological evidences) Indian Journal of Experimental Biology, 2010; 48, pp. 577-585.

[71] Hoglinger G, Feger J, Prigent A, Michel P, Parain K, Champy P, Ruberg M, Oertel W, Hirsh E (Chronic systemic complex I inhibition induces a hypokinetic multisystem degeneration in rats) J. Neurochem., 2003; 84, 491-502.

[72] Pan-Montojo F, Anichtchik O, Dening Y, Knels L, Pursche S, Jung, R, Jackson S, Gille G, Spillantini MG, Reichmann H, Funk R (Progression of Parkinson's Disease Pathology Is Reproduced by Intragastric Administration of Rotenone in Mice) PLoS ONE. 2010; 5 (1): e8762.

[73] Hirsch EC, Hunot S (Neuroinflammation in Parkinson's disease: A target for neuroprotection?) Lancet Neurol. 2009; 8, 382-397.

[74] Lotharius J, Brundin P (Pathogenesis of Parkinson's disease: dopamine, vesicles and $\alpha$-synuclein) Nat Rev Neurosci., 2002; 3 (12), 932-942.

[75] Jana S, Maiti AK, Bagh MB, Banerjee K, Das A, Roy A, Chakrabarti S (Dopamine but not 3,4- dihydroxy phenylacetic acid (DOPAC) inhibits brain respiratory chain activity by autooxidation and mitochondria catalyzed oxidation to quinone products: implications in Parkinson's disease) Brain Res., 2007; 1139: 195-200.
[76] Gao HM, Hong JS, Zhang W, Liu B. (Distinct role for microglia in rotenone-induced degeneration of dopaminergic neurons) J. Neurosci., 2002; 22, 782-790.

[77] LaVoie MJ, Hastings TG (Peroxynitrite- and nitrite-induced oxidation of dopamine: implications for nitric oxide in dopaminergic cell loss) J. Neurochem., 1999; 73, 2546-2554.

[78] Imam SZ, Newport GD, Itzhak Y, Cadet JL, Islam F, Slikker W, Ali SFJr (Peroxynitrite plays a role in methamphetamineinduced dopaminergic neurotoxicity: evidence from mice lacking neuronal nitric oxide synthase gene or overexpressing copper-zinc superoxide dismutase) J. Neurochem., 2001; 76, 745-749.

[79] Minghetti L (2004). (Cyclooxygenase-2 (COX-2) in inflammatory and degenerative brain diseases) J. Neuropathol. Exp. Neurol., 2004; 63, 901-910.

[80] Abdel-Rahman M, Ahmed HH, Moniem AE (Ameliorative effect of grape seed extract against rotenone-induced neurotoxicity in adult male albino rats) JASMR, 2008; 3 (2), 227-242.

[81] Jellinger K. (New developments in the pathology of Parkinson's disease) Adv Neurol., 1990; 53: 1-16.

[82] Zgaljardic DJ, Foldi NS, Borod JC (Cognitive and behavioral dysfunction in Parkinson's disease: neurochemical and clinicopathological contributions) J Neural Transm., 2004; 111:1287-1301.

[83] Zhang X, Lu L, Liu S, Ye W, Wu J. (Acetylcholinesterase deficiency decreases apoptosis in dopaminergic neurons in the neurotoxin model of Parkinson's disease. International Journal of Biochemistry) 2013; Vol. 45 Issue 2, p265-272. 8p.

[84] Shimada H, Hirano S, Shinotoh H, Aotsuka A, Sato K, Tanaka N, Ota T, Asahina M, Fukushi K, Kuwabara S, Hattori T, Suhara $\mathrm{T}$, Irie $\mathrm{T}$ (Mapping of brain acetylcholinesterase alterations in Lewy body disease by PET) Neurology, 2009; 73: $273-8$.

[85] Zarow C, Lyness SA, Mortimer JA, Chui HC (Neuronal loss is greater in the locus coeruleus than nucleus basalis and substantia nigra in Alzheimer and Parkinson diseases) Arch Neurol., 2003; 60: 337-41.

[86] Selden NR, Gitelman DR, Salamon-Murayama N, Parrish TB, Mesulam MM (Trajectories of cholinergic pathways within the cerebral hemispheres of the human brain) Brain, 1998; 121: $2249-57$.

[87] Sergei A, David A, Mei Q, Mark V. (Human Keratinocytes Synthesize, Secrete, and Degrade Acetylcholine) J Invest Dermatol., 1993; 101: 32-36.

[88] McKinney M, Coyle JT (The potential for muscarinic receptor subtype-specefic pharmacotherapy for Alzheimer's disease) Mayo Clin Proc., 1991; 66: 1225-1237.

[89] Jakeman P, Maxwell S. (Effects of antioxidant vitamin supplementation on muscle function after eccentric exercise) Eur J Appl Physiol., 1993; 67: 426-30.

[90] Makar TK, Nedergaard M, Preuss A, Gelbard AS, Perumal AS and Cooper AJ (Vitamin E, ascorbate, glutathione, glutathione disulfide, and enzymes of glutathione metabolism in cultures of chick astrocytes and neurons: evidence that astrocytes play an important role in antioxidative processes in the brain) Journal of Neurochemistry, 1994; 62: 45-53. 
[91] Wagner GC, Carelli RM, Jarvis MF (Ascorbic acid reduces the dopamine depletion induced by methamphetamine and the 1-methyl-4-phenylpyridinium ion) Neuropharmacology, 1986; 25: 559-561.

[92] Nehru B, Verma R, Khanna P, Sharma SK (Behavioral alterations in rotenone model of Parkinson's disease: attenuation by co-treatment of centrophenoxine) Brain Res., 2008; 1201: 122-7.
[93] Weiner D, Levey A, Brann M. (Expression of muscarian acetylcholine and dopamine receptor mRNAs in rat basal ganglia) Proc. Nati. Acad. Sci. USA., 1990; Vol. 87, pp. 70507054.

[94] Zhu W, Wang D, Zheng J, An Y, Wang Q, Zhang W, Jin L, Gao H, Lin L. (Effect of (R)-Salsolinol and N-Methyl-(R)Salsolinol on the Balance Impairment between Dopamine and Acetylcholine in Rat Brain: Involvement in Pathogenesis of Parkinson Disease) Clinical Chemistry, 2008; 54:4; 705-712. 